\title{
In vitro novel combinations of psychotropics and anti-cancer modalities in U87 human glioblastoma cells
}

\author{
SIVAN TZADOK ${ }^{1,6}$, EINAT BEERY ${ }^{1}$, MOSHE ISRAELI $^{7}$, ORIT UZIEL ${ }^{1,6}$, MEIR LAHAV $^{1,6}$, EYAL FENIG $^{4,6}$, \\ IRIT GIL-AD $^{1,6}$, ABRAHAM WEIZMAN ${ }^{1,2,6}$ and JARDENA NORDENBERG ${ }^{1,3,5,6}$ \\ ${ }^{1}$ Felsenstein Medical Research Center, ${ }^{2}$ Research Unit, Geha Mental Health Center, ${ }^{3}$ Endocrinology Laboratory and \\ ${ }^{4}$ Oncology Institute, Rabin Medical Center, Beilinson Campus, Petah Tikva 49100; ${ }^{5}$ Human Molecular Genetics \\ and Biochemistry, ${ }^{6}$ Sackler Faculty of Medicine, Tel Aviv University, Tel Aviv; ${ }^{7}$ CAIR Institute, \\ Goodman Faculty of Life Sciences, Bar-Ilan University, Ramat-Gan, Israel
}

Received May 14, 2010; Accepted July 8, 2010

DOI: 10.3892/ijo_00000756

\begin{abstract}
Glioblastoma multiforme (GBM) is a highly aggressive malignant brain tumor. Despite some recent improvement in the treatment of this malignancy, life expectancy of GBM patients remains extremely low. Therefore, continuous efforts to develop new treatment modalities are mandatory. A novel approach to cancer treatment is the use of targeted treatments, alone and in combination with other therapies. In this study, we evaluated the effects of novel combinations of conventional anti-cancer treatments (temozolomide or irradiation) with the targeted drug, imatinib, or with psychotropic drugs, belonging to the selective serotonin reuptake inhibitors (SSRIs) and phenothiazine subclasses, as well as combination of imatinib with psychotropic agents, on a human U87 glioblastoma cell line. The combination of temozolomide with imatinib or the psychotropic drugs resulted in an additive anti-proliferative effect, while the combination of irradiation and the psychotropic agents resulted in a less than additive effect on cell proliferation. A marked synergistic anti-proliferative effect of imatinib combined with the psychotropic drugs fluoxetine, sertraline or perphenazine was demonstrated. None of the single or combined treatments led to a reduction in the expression of phosphorylated MAP kinase. However, a marked synergistic reduction in the expression of the key regulatory molecule, pAKT, was detected, following the combined treatment of the cells with the imatinib/psychotropics combination. This downregulation of $\mathrm{pAKT}$ may mediate the synergistic antiproliferative interaction of imatinib with the psychotropic agents. Although the concentrations of the psychotropic agents used in this and other in vitro studies were beyond the
\end{abstract}

Correspondence to: Dr Jardena Nordenberg, Endocrinology Laboratory, Rabin Medical Center, Beilinson Campus, Petah Tikva 49100, Israel

E-mail: yardenan@clalit.org.il

Key words: U87, imatinib, selective serotonin reuptake inhibitors, psychotropic drugs, combined treatments clinically relevant blood levels in humans, recent studies have demonstrated anti-proliferative effects in vivo, using sertraline in a human colon cancer model. Thus, it seems that further in vivo studies combining imatinib with psychotropic agents, especially fluoxetine and sertraline, are warranted.

\section{Introduction}

Glioblastoma multiforme (GBM) is a highly aggressive malignant brain tumor. GBM is a genetically polymorphic malignancy with a variety of deletions, amplifications and point mutations. These molecular changes lead to the activation of signal transduction pathways downstream of tyrosine kinase receptors, such as epidermal growth factor receptor (EGFR), or platelet-derived growth factor receptor (PDGFR) $(1,2)$.

Despite some recent improvement in the treatment of this malignancy using the combined treatment of temozolomide (temodal) and irradiation $(3,4)$, the life expectancy of GBM patients remains extremely poor $(3,4)$. Therefore continuous efforts to develop new treatment modalities are needed. One novel approach to cancer treatment is the use of targeted rationalized treatments, directed towards key regulators of cell proliferation and apoptosis, alone and in combination with other treatments. Membranal receptors and intracellular proteins with tyrosine kinase activity involved in the cellular signal transduction pathways are the main targets for the development of novel anti-tumor agents.

Imatinib mesylate (Gleevec ${ }^{\circledR}$; STI571) was developed against the tyrosine kinase activity of the mutated $B C R-A B L$ gene product in chronic myeloid leukemia and proved to be highly effective against this type of leukemia. Subsequently, imatinib was found to inhibit the tyrosine kinase activity of stem cell factor (KIT), platelet-derived growth factor (PDGF), colony stimulating factor (CSF-1R) and discoidin domain (DDR) receptors and to be effective in the treatment of gastrointestinal stromal tumors (GIST) (5-8). GBM is characterized by the overexpression of the PDGFR as well as EGFR (9), which signal through RAS and protein kinase C (PKC) (9). U87 human glioblastoma cell line which overexpresses PDGFR and EGFR serves as an in vitro cellular model for glioblastoma (10). 
A recent report suggested that possible combinations of anti-PDGFR and EGFR agents with other treatment modalities could provide a better alternative for the treatment of GB tumors compared with monotherapy (11-15). Previous studies from our and other laboratories (16-19) have demonstrated the anti-tumor effect of psychotropic agents, such as antidepressants and antipsychotics. Our laboratory demonstrated that sigma receptor ligands, mainly haloperidol, possess pronounced anti-tumor activity. In our previous study, the combination of haloperidol and imatinib was found to exert a marked synergistic anti-proliferative effect on the SKMEL 28 human melanoma cell line (17).

In this study, we evaluated the effects of conventional combinations, as well as novel combinations on the human U87 glioblastoma cell line. We examined the in vitro effects of irradiation combined with temozolomide (the currently preferred treatment for human GBM), on cell proliferation. Novel combinations examined including treatment of U87 cells with the PDGF-targeted therapeutic agent, imatinib, combined with several psychotropic agents, belonging to the selective serotonin reuptake inhibitors (SSRIs) or phenothiazines. We assessed cell proliferation, intracellular ATP content and the phosphorylation state of AKT and mitogenactivated protein kinase (MAPK), key molecules implicated in the cellular effects of both imatinib and psychotropic agents (20-23).

\section{Materials and methods}

Materials. Imatinib (kindly provided by Novartis Pharmaceuticals, Basel, Switzerland), fluoxetine (Unipharm, RamatGan, Israel), sertraline (Ferring Pharmaceuticals, USA) and temozolomide (Schering-Plough Corporation, Germany) were dissolved in distillated water (10 $\mathrm{mM}$ stock) and kept frozen for up to 6 weeks. Perphenazine (Sigma, Israel) was dissolved in $1 \%$ lactic acid (10 $\mathrm{mM}$ stock) and kept frozen for up to 6 weeks. Sulphorhodamine B, Tris base, propidium iodide, trypan blue were obtained from Sigma.

Cell culture. U87 human glioblastoma cell line (kindly provided by Dr Gad Lavie, The Sheba Medical Center, Ramat-Gan, Israel) was maintained in DMEM (4.5 mg/l D-Glucose), supplemented with $10 \%$ fetal calf serum, $2 \mathrm{mM}$ glutamine and antibiotics (penicillin and streptomycin) which were obtained from Biological Industries (Beit Haemek, Israel). Cells were incubated at $37^{\circ} \mathrm{C}$, in a humidified atmosphere of $5 \% \mathrm{CO}_{2}$ and $95 \%$ air.

Cell proliferation. Cells $\left(1 \times 10^{4} / \mathrm{ml}\right)$ were seeded in quadruplicates in 24 well-plates in the presence or absence of several concentrations of the tested drugs alone or in combination. Imatinib was combined with each one of the following psychotropic drugs: fluoxetine, perphenazine, sertraline or temozolomide. Temozolomide was combined with perphe-nazine or sertraline. Cells were cultured for seven days and proliferation was assessed by the SRB assay (24). Briefly, cells were fixed with $10 \%$ trichloroacetic acid and stained with $0.4 \%$ sulphorhodamine B dissolved in $1 \%$ acetic acid. Unbound dye was removed by four repeated washes with acetic acid (1\%), and the dye-stained protein was extracted with unbuffered Tris base $(10 \mathrm{mM})$. The absorbance of the stained protein samples at $550 \mathrm{~nm}$ was determined, using a 96 well microtiter ELISA plate reader (PowerWave X, Bio Tek Instruments, Inc., USA).

The inhibitory effect of each agent added to the cultures was calculated as follows: Inhibition $(\%)=[1-(\mathrm{OD}$ of treated wells/OD of control wells)] x100. The theoretical additive inhibitory effect of two agents ( $a$ and $b$ ) was calculated as described in $(25,26)$, using the following equation: $I \mathrm{ab}=100 \mathrm{x}[1-(1-I \mathrm{a} / 100) \times(1-I \mathrm{~b} / 100)]$ where $I \mathrm{ab}$ is the calculated additive inhibitory effect expressed as \% inhibition. $I \mathrm{a}$ and $\mathrm{Ib}$ are the measured inhibitory effect $(\%)$ of each agent acting alone as compared with that of the control cultures. This equation was derived, assuming that the inhibitory agents act independently on the same target population.

Irradiation. Cells $\left(1 \times 10^{4}\right)$ were seeded in quadruplicates in 24 well-plates in the presence or absence of 5, $7 \mu \mathrm{M}$ perphenazine or 5, 7.5 $\mu \mathrm{M}$ sertraline. Cells were irradiated $1 \mathrm{~h}$ prior, $1 \mathrm{~h}$ after, or $24 \mathrm{~h}$ after the addition of the drugs, at radiation doses increasing from 0 to $8 \mathrm{~Gy}$, using a $6 \mathrm{MV}$ linear accelerator (Varian $600 \mathrm{C}$, Palo Alto, CA, USA). Cell proliferation was assessed seven days after seeding by the SRB colorimetric cytotoxicity assay.

Cell cycle and apoptosis analysis. Cells $\left(5 \times 10^{5} / 10 \mathrm{ml}\right.$ or $3 \times 10^{5} / 10 \mathrm{ml}$ ) were seeded for 2 or 5 days, respectively with $5 \mu \mathrm{M}$ perphenazine or $7.5 \mu \mathrm{M}$ sertraline or $15 \mu \mathrm{M}$ fluoxetine alone or with $10 \mu \mathrm{M}$ imatinib. Floating and adherent cells were combined, washed with PBS and nuclei were prepared from $5 \times 10^{5}-1 \times 10^{6}$ cells for the flow cytometric analysis, using trypsin, followed by staining of the nuclei with propidium iodide (27). DNA content was analyzed by FACSCalibur (Becton-Dickinson, San Jose, CA, USA), using ModFitLT cell cycle analysis software (Verity Software House Inc., Topsham, ME, USA).

Cells defined by FACS analysis in the pre-G1 stage of the cell cycle were suggested as possibly apoptotic. Apoptosis was also assessed by detecting DNA fragmentation using the Cell Death Detection ELISA ${ }^{\text {Plus }}$ kit (Roche, Mannheim, Germany). U87 cells $\left(1 \times 10^{4}\right)$ were seeded in each well of a 24-well plate. Cells were treated with $10 \mu \mathrm{M}$ imatinib, $5 \mu \mathrm{M}$ perphenazine, $7.5 \mu \mathrm{M}$ sertraline or $15 \mu \mathrm{M}$ fluoxetine alone or in combination with $10 \mu \mathrm{M}$ imatinib with each one of the psychotropic drugs. After 5 days, $0.25 \mathrm{ml}$ lysis buffer was added to each well and the supernatant was assayed for DNA fragments according to the manufacturer's instructions. The absorbance at 405 and $492 \mathrm{~nm}$ was measured using a microtiter ELISA plate reader. Identical replicate plates were analyzed for the estimation of cell number, using the SRB method. The results obtained from the DNA fragmentation assay were then normalized for cell numbers. Results were expressed as relative apoptosis to untreated cells (apoptotic index).

Determination of AKT and phosphorylated AKT (pAKT) protein expression. Cells $\left(5 \times 10^{5} / 10 \mathrm{ml}\right)$ were cultured without or with $10 \mu \mathrm{M}$ imatinib, $5 \mu \mathrm{M}$ perphenazine, $7.5 \mu \mathrm{M}$ sertraline or $15 \mu \mathrm{M}$ fluoxetine alone or in combination of $10 \mu \mathrm{M}$ imatinib with each one of the psychotropic drugs. After $24 \mathrm{~h}$, cells were harvested, washed with PBS and lysed using the 

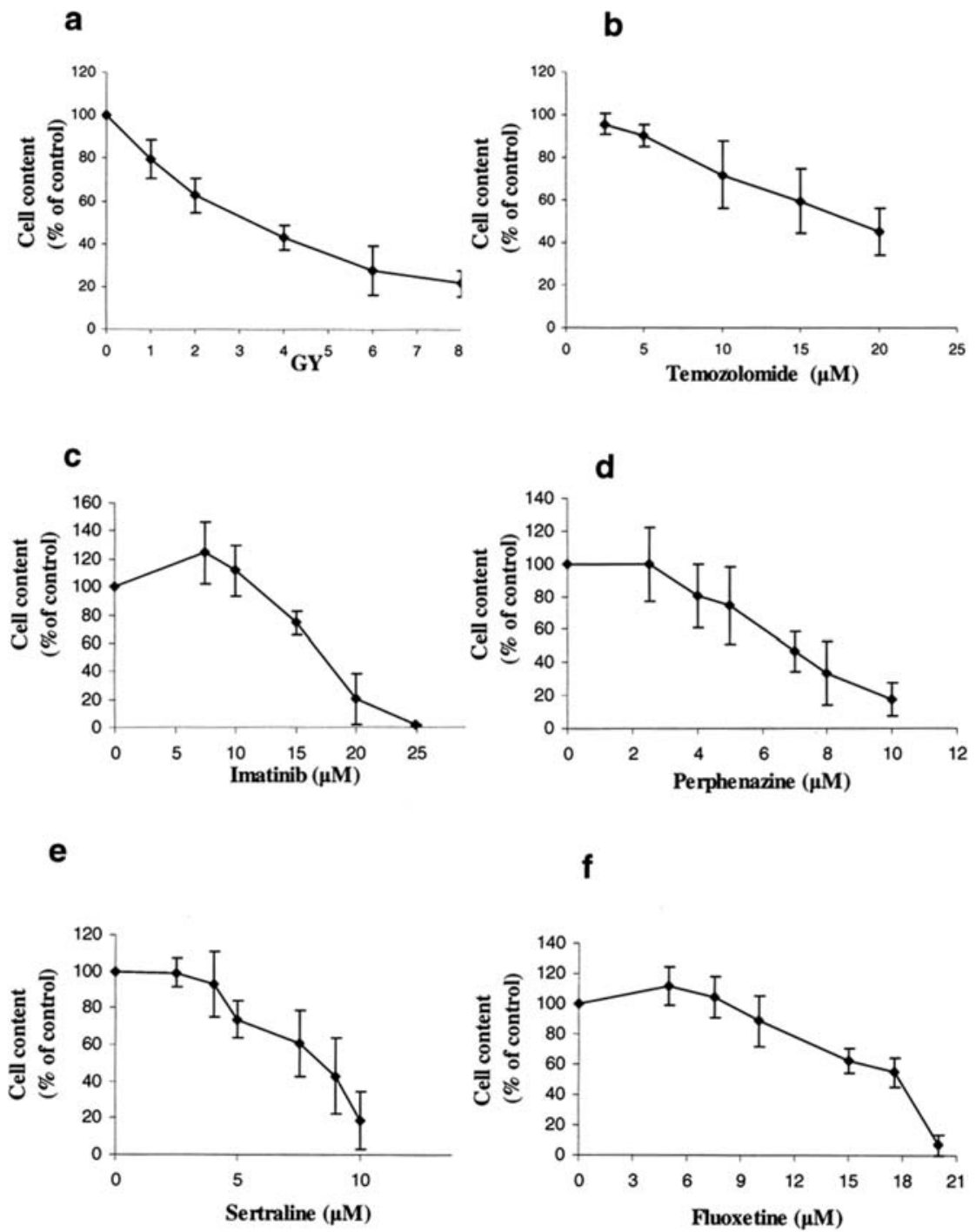

Figure 1. The effects of irradiation, temozolomide, imatinib and psychotropic drugs on U87 glioblastoma cell proliferation. U87 cells ( $1 \times 104 / \mathrm{ml})$ were treated with (a) irradiation, (b) temozolomide, (c) imatinib, (d) perphenazine, (e) sertraline or (f) fluoxetine for 7 days as described in Materials and methods. Adherent cells were assessed using the SRB assay. Results are expressed as mean \pm SEM of at least 3 independent experiments performed in quadruplicates.

TRAP kit CHAPS lysis buffer, containing phosphatase inhibitors. Protein concentration was determined using the Bradford assay (Bio-Rad Labs., Hercules, CA, USA). Identical protein amounts $(20 \mu \mathrm{g})$ of all samples were subjected to $10 \%$ SDS-PAGE. The AKT protein or the phosphorylated form of AKT protein were detected by specific polyclonal antibodies (Cell Signaling, SC, USA) in 1:1000 dilution, followed by HRP-conjugated goat anti-rabbit antibody (Jackson Lab., West Grove, PA, USA). B-actin was detected by monoclonal antibody (MP Biomedical, OH, USA) in 1:10,000 dilution, followed by HRP-conjugated goat antimouse (Jackson Lab., West Grove, PA, USA). The protein bands were detected by using a chemiluminescent kit (Sigma, USA) and quantified with the VersaDoc ${ }^{\text {TM }}$ Imaging System (Bio-Rad) using the Multi Analyst software.

Determination of MAPK and phosphorylated MAPK (pMAPK) protein expression. Cells $\left(1 \times 10^{6} / 10 \mathrm{ml}\right)$ were cultured for $24 \mathrm{~h}$ without or with $10 \mu \mathrm{M}$ imatinib or $15 \mu \mathrm{M}$ fluoxetine alone or in combination. Total cellular protein extracts were prepared $(50 \mu \mathrm{g})$ and separated as described above. MAPK (ERK 1 and 2) protein was detected using a rabbit polyclonal antibody (1:10,000 Sigma, St. Louis, MO, USA) followed by IRDye $^{\text {TM }} 680$ conjugated goat anti-rabbit IgG (1:10,000 LICOR, USA) and the phosphorylated form was detected using a mouse monoclonal antibody (1:10,000 Sigma) followed by IRDye $^{\text {TM }} 800$ conjugated goat anti-mouse $\operatorname{IgG}(1: 10,000$ LICOR, USA). Images were acquired with the Odyssey infrared imaging system (LI-COR, Lincoln, NB, USA) and analyzed by the software programs specified in the Odyssey manual.

Caspase 3-like activity. Cells $\left(1 \times 10^{6} / 10 \mathrm{ml}\right)$ were cultured for $24 \mathrm{~h}$ and then exposed to $5 \mu \mathrm{M}$ perphenazine, $7.5 \mu \mathrm{M}$ sertraline or $15 \mu \mathrm{M}$ fluoxetine combined with $10 \mu \mathrm{M}$ imatinib for $4,8,12$ or $24 \mathrm{~h}$. Adherent and non-adherent cells were collected and washed with PBS and the cell pellets were suspended in $120 \mu 1$ lysis buffer (28). After $30 \mathrm{~min}$ on ice, cell extracts were centrifuged for $6 \mathrm{~min}$ at $8900 \mathrm{~g}$. The supernatants were 
a

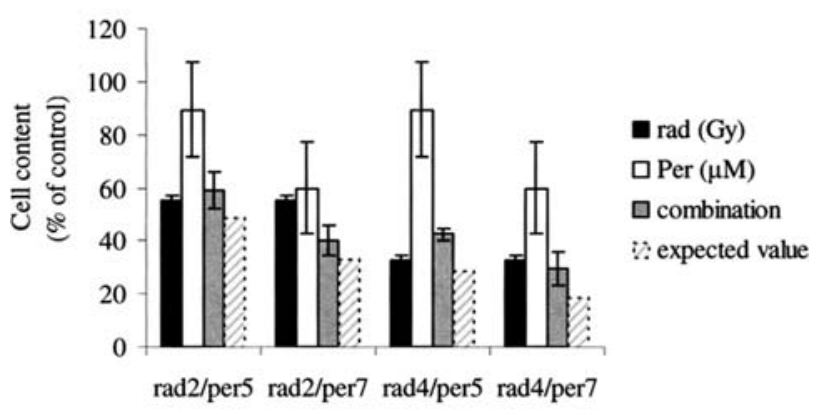

b

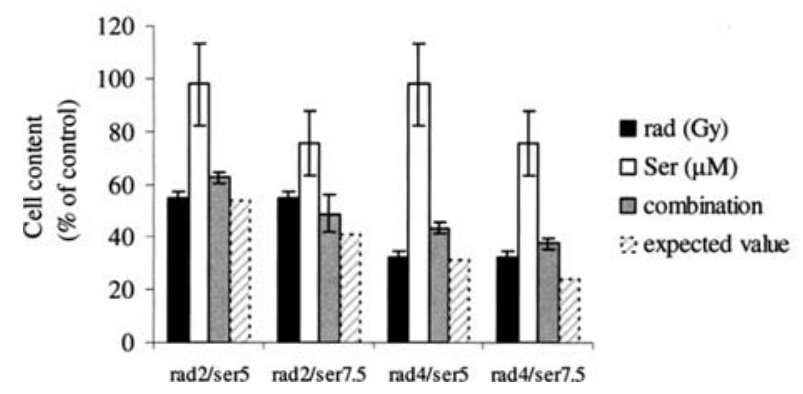

Figure 2. The effect of irradiation treatment combined with perphenazine or sertraline on U87 cell content. U87 cells $\left(1 \times 10^{4} / \mathrm{ml}\right)$ were seeded with (a) perphenazine (per) or (b) sertraline (ser). Twenty-four hours after, the cells were irradiated (rad) and incubated for additional 6 days. Proliferation was assessed using the SRB assay. Results are expressed as mean \pm SEM of at least 3 independent experiments performed in quadruplicates. The fourth bar in each section represents the expected calculated additive effect of the combined treatments on cell content.

collected and frozen immediately at $-70^{\circ} \mathrm{C}$ for at least $48 \mathrm{~h}$. Protein concentration was determined using the Bradford assay (29). Enzyme activity was determined using the fluorogenic substrate Ac-DEVD-AMC (Alexis Biochemical, Farmungdale, NY, USA), as previously described (28). Specific caspase activity was expressed as the ratio between the reaction rate (increase in fluorescence over time) and protein content.

ATP measurement. U87 cells $\left(5 \times 10^{5} / 10 \mathrm{ml}\right)$ were cultured in the presence or absence of $10 \mu \mathrm{M}$ imatinib, $5 \mu \mathrm{M}$ perphenazine, $7.5 \mu \mathrm{M}$ sertraline or $15 \mu \mathrm{M}$ fluoxetine alone, or in combination with $10 \mu \mathrm{M}$ imatinib for 4 or $24 \mathrm{~h}$. The cells were trypsinized, and viable cells were counted using the trypan blue exclusion test. Cells $\left(5 \times 10^{4}\right)$ were used. After washing, a lysing reagent was added to release intracellular ATP. A luciferin/luciferase mixture (part of ImmuKnowImmune Cell Function Assay kit, CYLEX incorporated, MD, USA) was then added to the cell lysates. Within 10 min after addition of the enzyme, the bioluminescent product was measured using the GloRunner microplate luminometer (Turner BioSystems, Sunnnyvale, CA, USA). The amount of the light emitted (emission maximum $562 \mathrm{~nm}$ ) was compared to a calibration curve generated with ATP calibrators $(0-1000 \mathrm{ng} / \mathrm{ml})$, and the ATP concentration in each sample was calculated using the ImmuKnow ${ }^{\mathrm{TM}}$ Data Analysis Software. a



b

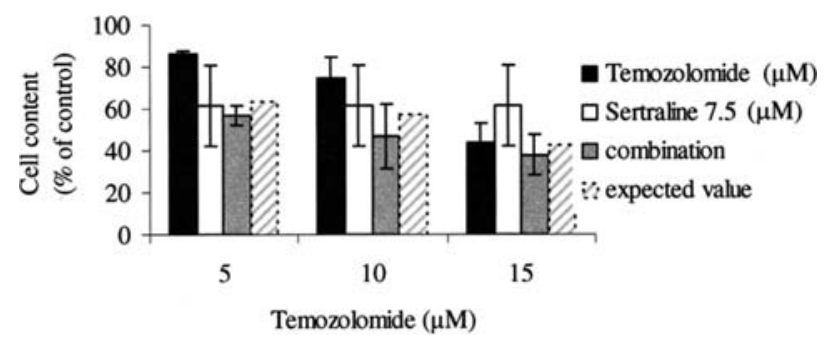

Figure 3. The effect of temozolomide treatment combined with perphenazine or sertraline on U87 cell content. U87 $\left(1 \times 10^{4} / \mathrm{ml}\right)$ cells were treated with temozolomide combined with (a) perphenazine or (b) sertraline for 7 days as described in Materials and methods. Proliferation was assessed using the SRB assay. Results are expressed as mean \pm SEM of at least 3 independent experiments performed in quadruplicates. The fourth bar in each section represents the expected calculated additive effect of the combined treatments on cell content.
Statistical analysis. The data are presented as mean $\pm \mathrm{SD}$, or mean \pm SEM. Each experiment was performed at least 3 times. The comparison between the groups was analyzed using Oneway analysis of variance (ANOVA), followed by Bonferroni post-hoc multiple comparisons test, or Student's t-test, as appropriate. A p $<0.05$ was considered statistically significant.

\section{Results}

The effects of irradiation, temozolomide, imatinib and psychotropic drugs on U87 glioblastoma cell proliferation. In this study we combined conventional treatment modalities for glioblastoma: irradiation or the chemotherapeutic agent temozolomide, with the tyrosine kinase inhibitor imatinib, or the psychotropic drugs, perphenazine, sertraline, or fluoxetine. Exposure of U87 human glioblastoma cells to increasing doses of irradiation (0-8 Gy), or to increasing concentrations of each of the following agents: temozolomide $(0-20 \mu \mathrm{M})$, the tyrosine kinase inhibitor imatinib $(0-25 \mu \mathrm{M})$ or the psychotropic agents perphenazine $(0-10 \mu \mathrm{M})$, sertraline $(0-10 \mu \mathrm{M})$, fluoxetine $(0-20 \mu \mathrm{M})$ for 7 days, resulted in a dose-dependent reduction in cell content (Fig. 1a-f). The $\mathrm{LD}_{50}$ for irradiation was $4 \mathrm{~Gy}$ and the $\mathrm{LC}_{50}$ for the different treatments were as follows: temozolomide: $18 \mu \mathrm{M}$, imatinib: $17.4 \mu \mathrm{M}$, perphenazine: $6.8 \mu \mathrm{M}$, sertraline: $8 \mu \mathrm{M}$ and fluoxetine $19 \mu \mathrm{M}$, respectively. 
a

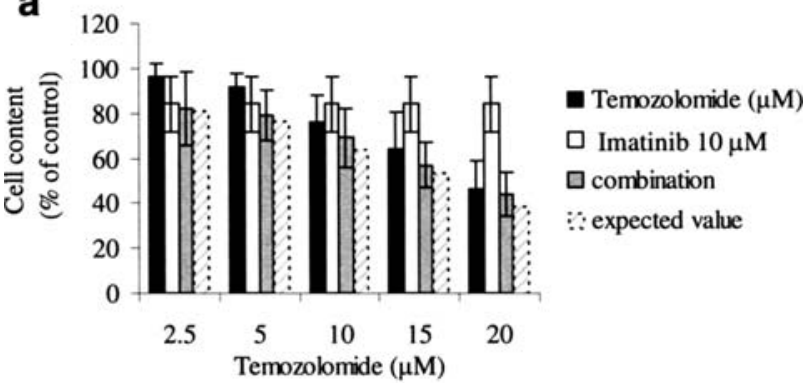

b

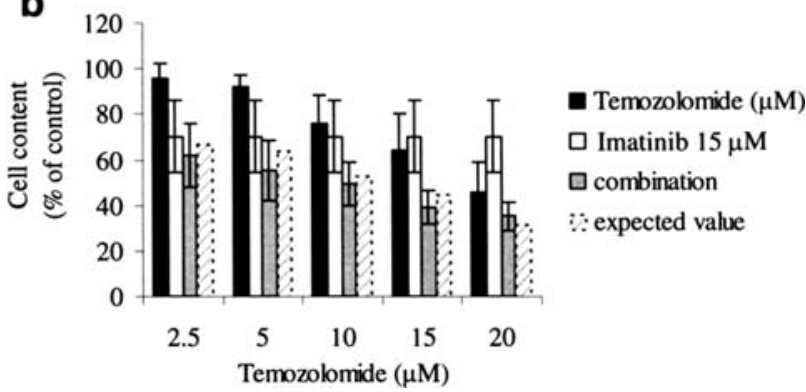

Figure 4. The effect of temozolomide combined with imatinib on U87 cell content. U87 cells $\left(1 \times 10^{4} / \mathrm{ml}\right)$ were treated with temozolomide combined with (a) $10 \mu \mathrm{M}$ imatinib or (b) $15 \mu \mathrm{M}$ imatinib for 7 days as described in Materials and methods. Proliferation was assessed using the SRB assay. Results are expressed as mean \pm SEM of at least 3 independent experiments performed in quadruplicates. The fourth bar in each section represents the expected calculated additive effect of the combined treatments on cell content.

The effects of combined treatments on U87 glioblastoma cell proliferation. In order to test the combined treatments, we used the dose of irradiation or the drug concentrations that inhibited cell proliferation by $50 \%$ or less.

The effect of combined treatments of irradiation with perphenazine or sertraline on U87 cell content. Fig. 2 shows the effect of the combination of irradiation with (a) perphenazine or with (b) sertraline, on cell content. These combinations of treatments resulted in a less than additive decrease in cell content, regardless whether perphenazine or sertraline were added $1 \mathrm{~h}$ before, immediately before or $1 \mathrm{~h}$ after irradiation (data not shown).

The effect of combined treatments of temozolomide with perphenazine or sertraline on U87 cell content. U87 cells were incubated with 5,10 or $15 \mu \mathrm{M}$ temozolomide, combined with $5 \mu \mathrm{M}$ perphenazine or $7.5 \mu \mathrm{M}$ sertraline for 7 days. An additive decrease in cell content was observed in all combinations (Fig. 3a and b).

The effect of combined treatment of temozolomide and imatinib on U87 cell content. As shown in Fig. 4a and b exposure of U87 cells to increasing concentrations of temozolomide $(0-20 \mu \mathrm{M})$ combined with 10 or $15 \mu \mathrm{M}$ imatinib for 7 days, resulted in an additive reduction in cell content.

The effect of combined treatments of imatinib with perphenazine, sertraline or fluoxetine on U87 cell content. We tested the effect of the combined treatments of imatinib with three psychotropic drugs: perphenazine, sertraline or fluoxetine. Fig. 5a-c shows that all the combinations decreased the cell content in a synergistic manner. Combined treatment was markedly and significantly more effective in reducing cell content, as compared to each individual treatment, or to a


C

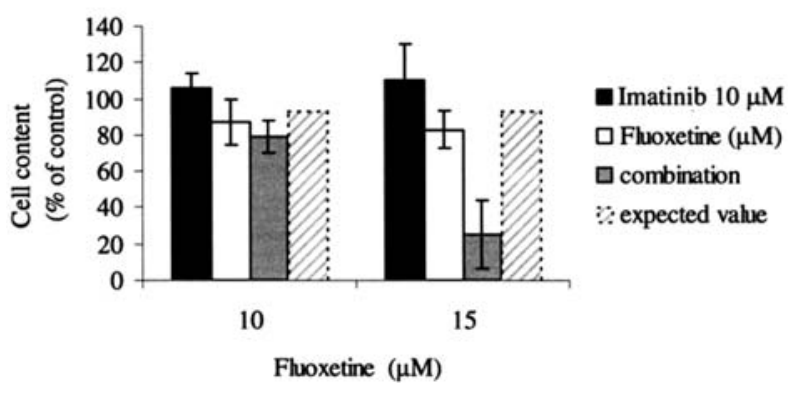

Figure 5. The effect of imatinib treatment combined with perphenazine, sertraline or fluoxetine on U87 cells. U87 cells $\left(1 \times 10^{4} / \mathrm{ml}\right)$ were treated with imatinib combined with (a) perphenazine or (b) sertraline or (c) fluoxetine for 7 days as described in Materials and methods. Proliferation was assessed using the SRB assay. Results are expressed as mean \pm SEM of at least 3 independent experiments performed in quadruplicates. The fourth bar in each section represents the expected calculated additive effect of the combined treatments on cell content. In the ANOVA test and independent samples t test, the following abbreviations were used: im, imatinib; per, perphenazine; imp, imatinib + perphenazine; ser, sertraline; ims, imatinib + sertraline; flu, fluoxetine; imf, imatinib + fluoxetine. $F(7,50)=6.6745$ (a) im10 vs. per2.5 $(\mathrm{p}=0.131), \mathrm{imp}$ vs. per2.5 ( $\mathrm{p}=0.001), \mathrm{imp}$ vs. $\operatorname{im} 10(\mathrm{p}=0.014), \mathrm{t}(\mathrm{df}=6)=-3.301$, $\mathrm{p}<0.005$ observed vs. expected $\mathrm{F}(2,9)=35.346$ im10 vs. per5 $(\mathrm{p}=0.998)$, imp vs.per5 ( $\mathrm{p}=0.002), \operatorname{imp}$ vs. $\operatorname{im} 10(\mathrm{p}=0.002), \mathrm{t}(\mathrm{df}=6)=-8.043, \mathrm{p}<0.005$ observed vs expected $\mathrm{F}(2,9)=31.052 \mathrm{im} 10$ vs. per7 $(\mathrm{p}=0.310)$, imp vs. per7 $(\mathrm{p}=0.016)$, imp vs. im10 $(\mathrm{p}<0.001), \mathrm{t}(\mathrm{df}=3.09)=-5.639, \mathrm{p}<0.005$ observed vs. expected 5(b).im 10 vs. ser7.5 ( $\mathrm{p}=0.086)$, ims vs. ser7.5 ( $\mathrm{p}=0.007)$, ims vs. $\operatorname{im} 10(\mathrm{p}=0.001), \mathrm{t}(\mathrm{df}=6)=-4.444, \mathrm{p}<0.005$ observed vs. expected $\mathrm{F}(2,6)=49.114 \mathrm{im} 10$ vs. $\operatorname{ser} 10(\mathrm{p}=0.070)$, ims vs.ser10 $(\mathrm{p}=0.0017)$, ims vs. im $10(\mathrm{p}=0.007), \mathrm{t}(\mathrm{df}=4)=-5.244, \mathrm{p}<0.005$ observed vs. expected $\mathrm{F}(2,6)=98.123 \mathrm{im} 10$ vs. $\operatorname{ser} 12.5(\mathrm{p}=0.028)$, ims vs.ser12.5 $(\mathrm{p}=0.421)$, ims vs . $\operatorname{im} 10(\mathrm{p}=0.001), \mathrm{t}(\mathrm{df}=2.0)=-2.153, \mathrm{p}>0.005$ observed vs. expected $\mathrm{F}(2,9)=23.733$ (c). im10 vs. flu15 ( $\mathrm{p}=0.217)$, imf vs. flu15 ( $\mathrm{p}=0.010)$, imf vs. $\operatorname{im} 10(\mathrm{p}=0.004), 5(\mathrm{df}=6)=-4.021, \mathrm{p}<0.005$ observed vs. expected $\mathrm{F}(2,6)=5.301 \mathrm{im} 10$ vs. flu10 ( $\mathrm{p}=0.298)$, imf vs. flu10 ( $\mathrm{p}=0.827)$, imf vs. im10 $(\mathrm{p}=0.062), \mathrm{t}(\mathrm{df}=4)=-1.035, \mathrm{p}>0.005$ observed vs expected.

the expected additive interaction between the drugs. Similar results were obtained when imatinib and the corresponding psychotropics were added to the cell culture at the same time, 
Table I. The effect of imatinib alone and in combination with psychotropic agents on sub G1 fraction in U87 cells.

\begin{tabular}{lrr}
\hline Treatment & & Sub-G1 fraction $(\%)$ \\
\cline { 2 - 3 } Duration & 2 days & 5 days \\
\hline Untreated cells & $12.3 \pm 1.7$ & $11.3 \pm 1.4$ \\
Imatinib $10 \mu \mathrm{M}$ & $13.0 \pm 2.4$ & $12.4 \pm 1.8$ \\
Perphenazine $5 \mu \mathrm{M}$ & $12.4 \pm 1.9$ & $16.7 \pm 4.1$ \\
Sertraline $7.5 \mu \mathrm{M}$ & $14.3 \pm 2.4$ & $15.6 \pm 1.9$ \\
Fluoxetine $15 \mu \mathrm{M}$ & $15.3 \pm 2.1$ & $15.5 \pm 2.3$ \\
Imatinib $10 \mu \mathrm{M}+$ Perphenazine $5 \mu \mathrm{M}$ & $21.0 \pm 3.7$ & $20.6 \pm 2.5$ \\
Imatinib $10 \mu \mathrm{M}+$ Sertraline $7.5 \mu \mathrm{M}$ & $23.2 \pm 3.5$ & $25.1 \pm 5.4$ \\
Imatinib $10 \mu \mathrm{M}+$ Fluoxetine $15 \mu \mathrm{M}$ & $24.8 \pm 1.1$ & $48.1 \pm 6.6^{\mathrm{a}}$ \\
ANOVA & $\mathrm{F}(7,71)=3.18, \mathrm{p}<0.05$ & $\mathrm{~F}(7,87)=10.63, \mathrm{p}<0.0001$ \\
\hline
\end{tabular}

Cells were incubated for 2 or 5 days and cell cycle was assessed as described in Materials and methods. The results represent means \pm SEM of 5 independent experiments performed in duplicates. ${ }^{a} \mathrm{p}<0.05$ vs. untreated, imatinib, fluoxetine, or imatinib + perphenazine groups.



Figure 6. The effect of imatinib treatment combined with psychotropic drugs on cell cycle. U87 cells $\left(3 \times 10^{5} / 10 \mathrm{ml}\right)$ were treated with imatinib combined with perphenazine or sertraline or fluoxetine for 5 days. Nuclei were isolated, stained and DNA content was analyzed by FACS as described in Materials and methods. Results are expressed as mean \pm SEM of at least 5 independent experiments performed in duplicates. c, control; im, imatinib $(10 \mu \mathrm{M})$; per, perphenazine $(5 \mu \mathrm{M})$; ser, sertraline $(7.5 \mu \mathrm{M})$; flu, fluoxetine $(15 \mu \mathrm{M})$; imp, imatinib $(10 \mu \mathrm{M})+$ perphenazine $(5 \mu \mathrm{M})$; ims, imatinib $(10 \mu \mathrm{M})+$ sertraline $(7.5 \mu \mathrm{M})$; imf, imatinib $(10 \mu \mathrm{M})+$ fluoxetine $(15 \mu \mathrm{M})$. In ANOVA test$F(7,78)=10.799$, a small but significant elevation was found in $G 2 / \mathrm{M}: \mathrm{c}$ vs. $\operatorname{imp}(\mathrm{p}=0.007), \mathrm{c}$ vs. ims $(\mathrm{p}<0.001), \mathrm{c}$ vs. $\operatorname{imf}(\mathrm{p}=0.001)$, ser vs. ims $(\mathrm{p}<0.001)$ im vs. ims $(\mathrm{p}=0.035)$, flu vs. $\operatorname{imf}(\mathrm{p}=0.014)$.

or whether imatinib was added one day before, or one day after the addition of the psychotropic drugs (data not shown).

The effect of combined treatment of imatinib with psychotropic drugs on cell cycle. Since the combined treatment of imatinib and psychotropic drugs was the most efficient in their growth inhibitory effect, these combinations were further explored. To determine whether the synergistic antiproliferative effect of any combination was mediated via cell cycle arrest, we compared the cell cycle profile of the untreated U87 cells to that of the U87 cells following exposure for 2 and 5 days to $10 \mu \mathrm{M}$ imatinib with or without $5 \mu \mathrm{M}$ perphenazine, $7.5 \mu \mathrm{M}$ sertraline or $15 \mu \mathrm{M}$ fluoxetine. After 2 days of exposure no significant changes in cell cycle status were observed, except for a modest decrease in G0/G1 of cells treated with imatinib (data not shown). After 5 days of combined treatment of cells, there were small but significant increases in $\mathrm{G} 2 / \mathrm{M}$, accompanied by a slight decrease in $\mathrm{G} 0 / \mathrm{G} 1$. In contrast, no significant changes in the cell cycle profile were detected following the exposure to imatinib, or to each one of the three psychotropic drugs alone (Fig. 6).

These minor changes in the cell cycle profile could not explain the marked reduction in cell content after the exposure to the combined treatments. To investigate whether the synergistic decrease in cell content of the combined treatment of imatinib and psychotropic drugs is due to an apoptotic effect, we measured the pre-G1 phase of the cell cycle (analyzed by FACS) after 2 and 5 days of treatment. As shown in Table I, there were no significant increases in the pre-G1 fraction of each treatment alone after 2 or 5 days of exposure to the single drugs, compared to untreated cells. Only the combination of imatinib with fluoxetine resulted in a significant increase in the sub-G1 fraction following 5 days of combined treatment (Table I).

Similar results were obtained when DNA fragmentation was analyzed on day 5 using the cell death detection ELISA ${ }^{\text {Plus }}$

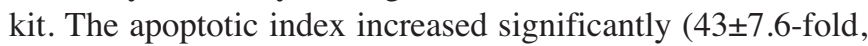
$\mathrm{p}<0.0001$ vs. untreated cells) only in cells exposed to the combined treatment of imatinib $10 \mu \mathrm{M}+$ fluoxetine $15 \mu \mathrm{M}$. In order to examine whether the increase in the apoptotic index following the combined treatment of imatinib with fluoxetine occurred via caspase- 3 activation, we measured the specific activity of the enzyme 4, 8, 12 and $24 \mathrm{~h}$ after the addition of the drugs alone or in combination. Caspase 3 activity was not significantly affected by any type of treatment at all time point examined (data not shown).

The effect of imatinib treatment combined with psychotropic drugs on the intracellular ATP content. Previous studies from our and other laboratories revealed a reduction in intracellular ATP content following the treatment of cancer cells with psychotropic drugs $(17,30)$. Imatinib was reported to reduce ATP content in cardiomyocytes (31). To examine whether the cell death of U87 cells occurred via an early 


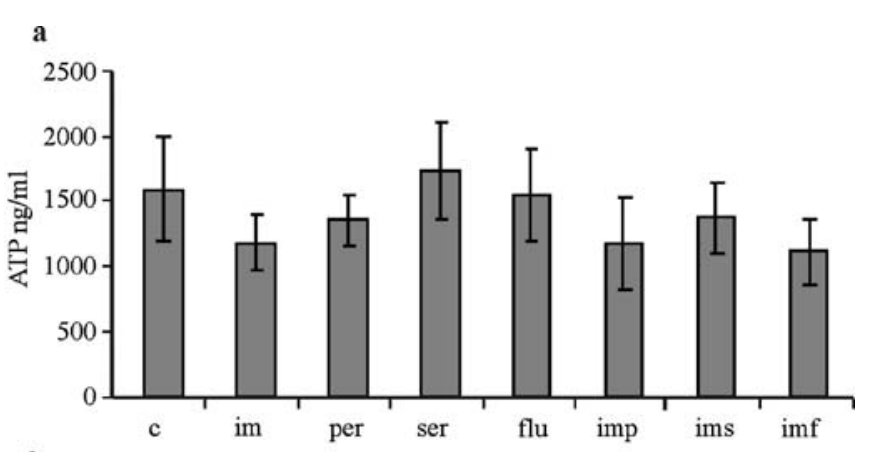

b

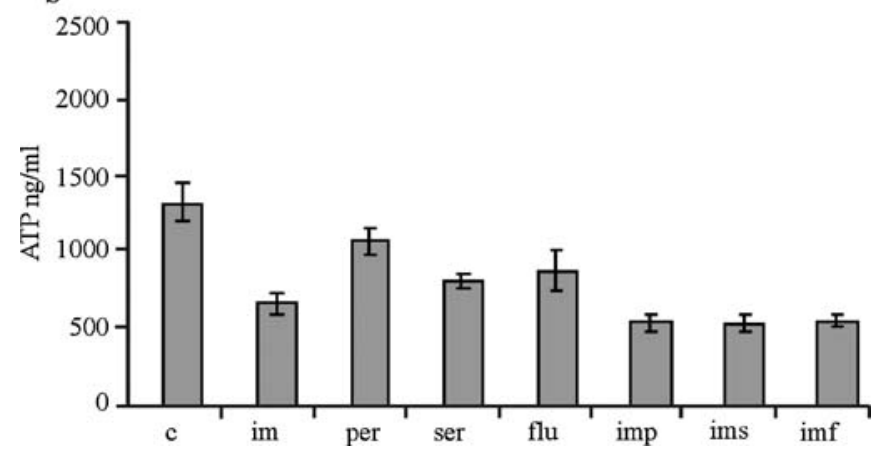

Figure 7. The effect of imatinib treatment combined with psychotropic drugs for 4 and $24 \mathrm{~h}$ on the intracellular ATP content. U87 cells $\left(5 \times 10^{5} / 10 \mathrm{ml}\right)$ were incubated without control (c), or with imatinib (im; $10 \mu \mathrm{M}$ ), or psychotropic drugs [per, perphenazine $(5 \mu \mathrm{M})$; ser, sertraline $(7.5 \mu \mathrm{M})$; flu, fluoxetine $(15 \mu \mathrm{M})$ ] alone or in combination [ims, imatinib $(10 \mu \mathrm{M})+$ perphenazine $(5 \mu \mathrm{M})$; ims, imatinib $(10 \mu \mathrm{M})+\operatorname{sertraline}(7.5 \mu \mathrm{M})$; imf, imatinib $(10 \mu \mathrm{M})$ + fluoxetine $(15 \mu \mathrm{M})]$ for (a) $4 \mathrm{~h}$ or (b) $24 \mathrm{~h}$. The results are expressed as means \pm SEM of 3 independent experiments performed in duplicates. In the ANOVA test after $4 \mathrm{~h}(\mathrm{a}): \mathrm{F}(7,39)=0.535 \mathrm{c}$ vs. im $(\mathrm{p}=1)$, c vs. per $(\mathrm{p}=1)$, c vs. $\operatorname{ser}(p=1)$, c vs. flu $(p=1)$, c vs. imp $(p=1), c$ vs. ims $(p=1), c$ vs. imf $(\mathrm{p}=1)$. In the ANOVA test after $24 \mathrm{~h}(\mathrm{~b}): \mathrm{F}(7,50)=13.76 \mathrm{c}$ vs. im $(\mathrm{p}=0.016)$, c vs. per $(p=979), c$ vs ser $(p=0.08)$, c vs. flu $(p=0.694), c$ vs. imp $(p=0.002)$, c vs. ims $(\mathrm{p}=0.002), \mathrm{c}$ vs. $\operatorname{imf}(\mathrm{p}=0.004)$.

mitochondrial injury, we measured the intercellular ATP levels following single and combined exposure to imatinib and the psychotropic agents.

$\mathrm{U} 87$ cells were exposed to $10 \mu \mathrm{M}$ imatinib or $5 \mu \mathrm{M}$ perphenazine or $7.5 \mu \mathrm{M}$ sertraline or $15 \mu \mathrm{M}$ fluoxetine alone, or a combination of each of the psychotropic agents with imatinib for 4 and $24 \mathrm{~h}$. No significant decrease in ATP level was observed in cells treated with $10 \mu \mathrm{M}$ of imatinib for $4 \mathrm{~h}$ (Fig. 7a. ANOVA: $\mathrm{F}=0.535, \mathrm{DF}=7,39 \mathrm{NS}$ ). After $24 \mathrm{~h}$ of treatment, a marked significant reduction in ATP content was noted in cells treated with imatinib (Fig 7b. ANOVA: $F=13.76$, $\mathrm{DF}=7,50, \mathrm{p}<0.01)$. The psychotropic drugs alone did not significantly affect the intracellular ATP content. The combinations of imatinib with each one of the psychotropic agents resulted in a marked decrease in ATP content. However, this increase did not exceed that induced by the imatinib alone (Fig. 7a and b).

The effect of imatinib treatment combined with psychotropic drugs on pAKT/AKT expression. U87 cells highly express the phosphorylated form of AKT. Treatment of the cells for $24 \mathrm{~h}$ with $10 \mu \mathrm{M}$ imatinib, $5 \mu \mathrm{M}$ perphenazine, $7.5 \mu \mathrm{M}$ sertraline, $15 \mu \mathrm{M}$ fluoxetine did not affect the phosphorylation status of
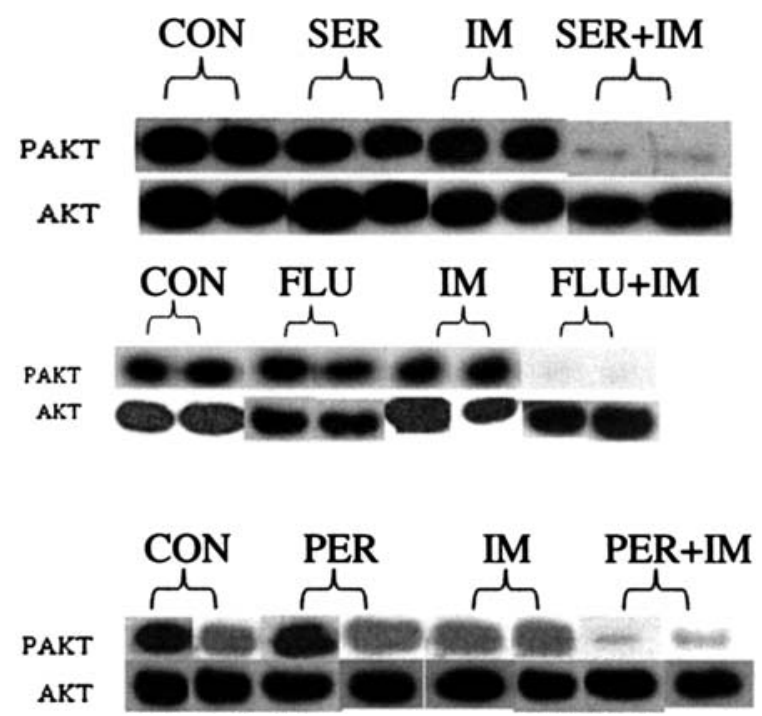

Figure 8 . The effect of psychotropic drugs, imatinib and their combinations on the phosphorylation of AKT in U87 cells. U87 cells $\left(5 \times 10^{5} / 10 \mathrm{ml}\right)$ were incubated without CON (control) or with IM (imatinib; $10 \mu \mathrm{M}$ ) or with psychotropic drugs [SER, sertraline $(7.5 \mu \mathrm{M})$ ] FLU, fluoxetine $(15 \mu \mathrm{M})$, PER, perphenazine $(5 \mu \mathrm{M})]$ alone or in combinations [SER + IM, sertraline $(7.5 \mu \mathrm{M})+$ imatinib $(10 \mu \mathrm{M})$; FLU + IM, fluoxetine $(15 \mu \mathrm{M})+$ imatinib $(10 \mu \mathrm{M}) ; \mathrm{PER}+\mathrm{IM}$, perphenazine $(5 \mu \mathrm{M})+$ imatinib $(10 \mu \mathrm{M})]$ for $24 \mathrm{~h}$. The figure shows a representative experiment (one out of at least 6 consistent independent replications).

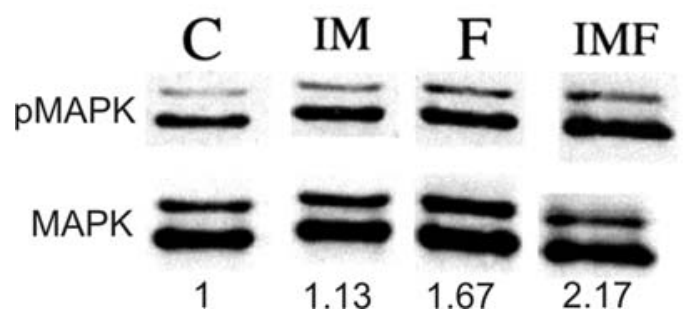

Figure 9. The effect of combined treatments of imatinib with fluoxetine on the phosphorylation of MAPK in U87 cells. U87 cells $\left(1 \times 10^{6} / 10 \mathrm{ml}\right)$ were incubated without $(\mathrm{C}$, control) or with imatinib (IM; $10 \mu \mathrm{M})$, fluoxetine $(\mathrm{F}$; $15 \mu \mathrm{M})$ alone or in combination [IMF, imatinib $(10 \mu \mathrm{M})+$ fluoxetine $(15 \mu \mathrm{M})$ ] for $24 \mathrm{~h}$. The figure shows a representative experiment (one out of at least 3 consistent independent replications).

AKT. However, treatment with imatinib combined with fluoxetine or sertraline resulted in a marked significant decrease (63\%, 70\% respectively, $\mathrm{p}<0.05$ vs. control for both) in the phosphorylated form of AKT $(\mathrm{F}=6.08, \mathrm{DF}=7.45, \mathrm{p}<0.0001)$. The combination of perphenazine with STI 571 resulted in a mean $53 \%$ reduction in pAKT. A marked reduction was observed in 4 out of 6 independent experiments. However, the mean suppression did not reach statistical significance, $\mathrm{p}=0.2$ ). The total AKT and $\beta$-actin remained almost unchanged after all treatments administered (Fig. 8).

The effect of imatinib treatment combined with psychotropic drugs on MAPK/pMAPK expression. Treatment of U87 cells for $24 \mathrm{~h}$ with $10 \mu \mathrm{M}$ imatinib or $15 \mu \mathrm{M}$ fluoxetine led to a minor non-significant increase in the amount of the phosphorylated form of MAPK (pMAPK). The combined 
treatment of imatinib with fluoxetine resulted in an increase $(197 \%, \mathrm{p}<0.01)$ in pMAPK expression. $(\mathrm{F}=6.84, \mathrm{DF}=3.12$, $\mathrm{p}<0.01$ ). Total MAPK did not change significantly (Fig. 9). The effect of $5 \mu \mathrm{M}$ perphenazine alone or in combination with $10 \mu \mathrm{M}$ imatinib on pMAPK was not significant (data not shown).

\section{Discussion}

In this study we demonstrated a synergistic anti-proliferative effect of the targeted therapeutic agent imatinib with the psychotropic agents, fluoxetine, sertraline (SSRIs) and perphenazine (a phenothiazine) on the U87 human glioblastoma cell line. We have previously reported similar synergistic interactions of imatinib with the psychotropic drug haloperidol (a sigma receptor ligand) in SK-MEL-28 human melanoma cells (17). The combination of imatinib with temozolomide, the currently most effective chemotherapeutic agent for the treatment of glioblastoma, resulted only in an additive antiproliferative effect (Fig. 4). It is of note that pretreatment of a human glioblastoma cell line, RuSi RS1, with imatinib, significantly enhanced the cytotoxic effect of ionizing radiation (11). ABL kinase activity is implicated in DNA repair (32), and as an inhibitor imatinib can therefore potentiate DNAdamage caused by radiation or chemotherapeutic agents acting via DNA damage.

The combination of temolozomide with the psychotropic agents resulted in an additive anti-proliferative effect (Fig. 3), while the combination of irradiation and the psychotropic agents resulted in a less than additive effect on cell proliferation (Fig. 2). A recent report of Ren et al (33), showed a differential sensitivity of several glioblastoma cell lines to imatinib. Synergistic anti-tumor effects were found with the chemotherapeutic drugs temolozomide or hydroxyurea. However, in accordance with our results, no synergism could be detected on U87 cells. In this study we demonstrated for the first time a marked synergistic anti-proliferative effect of imatinib and psychotropic drugs on U87 cells (Fig. 5).

The cell cycle profile was not affected significantly by any of the single or combined treatments. Imatinib was shown to induce cell cycle arrest of glioma cells with a corresponding elevation in cyclin-dependent kinases. However these effects were not obtained in the U87 glioma cell line (33). The synergistic interaction between imatinib and the psychotropic agents on cell content does not seem to be related to a pro-apoptotic mechanism, since only one of the combinations (fluoxetine and imatinib) demonstrated an increase in sub-G1 fraction (Table I), which can also indicate other types of cell death. Moreover, the combined treatment did not alter caspase- 3 activity, which is a marker of apoptosis. Interestingly, imatinib led to a significant reduction in intracellular ATP levels, which was not further augmented significantly by the addition of the psychotropic agents (Fig. 7). It may be speculated that the reduction of ATP induced by imatinib may contribute to a perturbation of the cell membrane, thus enhancing the effects of psychotropic agents, which have recently been reported to affect membranal lipid homeostasis (34).

In this study, we show a marked synergistic reduction in the expression of the key regulatory molecule pAKT, following the combined treatment of the cells with imatinib and the psychotropics, sertraline, perphenazine and fluoxetine (Fig. 8). This finding suggests that the anti-proliferative synergism may be mediated by the marked decrease in pAKT levels. It should be noted that in our study, imatinib alone did not alter pAKT cellular expression. Other studies have shown different effects on pAKT, depending on the cell line used (19).

Since MAPK is a major regulator of cell proliferation, we assessed the effects of imatinib and the psychotropic drugs alone and in combination, on its expression. None of the single or combined treatments led to a reduction in the expression of the active phosphorylated form of MAPK (pMAPK). However, the combination of fluoxetine with imatinib resulted in an increase of pMAPK (Fig. 9). The role of this activation in the synergistic anti-proliferative effect of fluoxetine and imatinib in U87 cells is currently unclear. It is of interest to note that the activation of MAPK by sertraline in hepatoma cells and fluoxetine in rat astrocytes has previously been reported $(22,35)$. It should also be noted that in several osteosarcoma cell lines, imatinib was shown to reduce pAKT, while pMAPK remained constitutively activated (36). In a recent study it has been reported that the flavonoid, $n$ arginine, inhibited vascular smooth muscle proliferation via the activation of the ERK signaling pathway (37).

It is known that imatinib uptake into cells is often mediated by the OCT1 transporter, with MDR-1 being responsible for efflux (38-40). It is therefore possible that the effects observed in this study relate to effects on intracellular concentrations of imatinib. Although the concentrations of the psychotropic agents used in this and other in vitro studies were beyond the clinically relevant blood levels achieved in humans treated for psychiatric disorders, recent studies have demonstrated an anti-proliferative effect of sertraline in an in vivo human colon cancer model (41). Thus, it seems that further in vivo studies combining imatinib with psychotropic agents, especially fluoxetine and sertraline, are warranted.

\section{Acknowledgements}

This research was partially supported by The Sackler Faculty of Medicine Research Fund, Tel Aviv University, Tel Aviv, Israel.

\section{References}

1. Holland EC: Glioblastoma multiforme: the terminator. Proc Natl Acad Sci USA 97: 6242-6244, 2000.

2. Maher EA, Furnari FB, Bachoo MR, Rowitch DH, Louis DN, Cavenee WK and DePinho RA: Malignant glioma: genetics and biology of a grave matter. Genes Dev 15: 1311-1333, 2001.

3. Stupp R, Mason WP, van den Bent MJ, et al: Radiotherapy plus concomitant and adjuvant temozolomide for glioblastoma. $\mathrm{N}$ Engl J Med 352: 987-996, 2005.

4. Mirimanoff RO, Gorlia T, Mason W, et al: Radiotherapy and temozolomide for newly diagnosed glioblastoma: recursive partitioning analysis of the EORTC 26981/22981-NCIC CE3 phase III randomized trial. J Clin Oncol 24: 2563-2569, 2006.

5. Heinrich MC, Griffith DJ, Druker BJ, Wait CL, Ott KA and Zigler AJ: Inhibition of c-kit receptor tyrosine kinase activity by STI 571, a selective tyrosine kinase inhibitor. Blood 96: 925-932, 2000.

6. Buchdunger E, Cioffi CL, Law N, Stover D, Ohno-Jones S, Druker BJ and Lydon NB: Abl protein-tyrosine kinase inhibitor STI571 inhibits in vitro signal transduction mediated by c-kit and platelet-derived growth factor receptors. J Pharmacol Exp Ther 295: 139-145, 2000. 
7. Day E, Waters B, Spiegel K, Alnadaf T, Manley PW, Buchdunger $\mathrm{E}$, Walker $\mathrm{C}$ and Jarai G: Inhibition of collageninduced discoidin domain receptor 1 and 2 activation by imatinib, nilotinib and dasatinib. Eur J Pharmacol 599: 44-53, 2008.

8. Verweij J, van Oosterom A, Blay JY, et al: Imatinib mesylate (STI-571 Glivec, Gleevec) is an active agent for gastrointestinal stromal tumours, but does not yield responses in other softtissue sarcomas that are unselected for a molecular target. Results from an EORTC Soft Tissue and Bone Sarcoma Group phase II study. Eur J Cancer 39: 2006-2011, 2003.

9. Feldkamp MM, Lau N and Guha A: Signal transduction pathways and their relevance in human astrocytomas. J Neurooncol 35: 223-248, 1997

10. Pollack IF, Randall MS, Kristofik MP, Kelly RH, Selker RG and Vertosick FT: Response of malignant glioma cell lines to epidermal growth factor and platelet-derived growth factor in a serum-free medium. J Neurosurg 73: 106-112, 1990.

11. Holdhoff M, Kreuzer KA, Appelt C, et al: Imatinib mesylate radiosensitizes human glioblastoma cells through inhibition of platelet-derived growth factor receptor. Blood Cells Mol Dis 4: $181-185,2005$

12. Oertel S, Krempien R, Lindel K, et al: Human glioblastoma and carcinoma xenograft tumors treated by combined radiation and imatinib (Gleevec). Strahlenther Onkol 82: 400-407, 2006.

13. Dresemann G: Imatinib and hydroxyurea in pretreated progressive glioblastoma multiforme: a patient series. Ann Oncol 16 : 1702-1708, 2005.

14. Efferth T, Ramirez T, Gebhart E and Halatsch ME: Combination treatment of glioblastoma multiforme cell lines with the antimalarial artesunate and the epidermal growth factor receptor tyrosine kinase inhibitor OSI-774. Biochem Pharmacol 67: 1689-1700, 2004.

15. Eller JL, Longo SL, Kyle MM, Bassano D, Hicklin DJ and Canute GW: Anti-epidermal growth factor receptor monoclonal antibody cetuximab augments radiation effects in glioblastoma multiforme in vitro and in vivo. Neurosurgery 56: 155-162, 2005.

16. Nordenberg J, Fenig E, Landau M, Weizman R and Weizman A Effects of psychotropic drugs on cell proliferation and differentiation. Biochem Pharmacol 58: 1229-1236, 1999.

17. Nordenberg J, Perlmutter I, Lavie G, Beery E, Uziel O, Morgenstern C, Fenig E and Weizman A: Anti-proliferative activity of haloperidol in B16 mouse and human SK-MEL-28 melanoma cell lines. Int J Oncol 27: 1097-1103, 2005.

18. Gil-Ad I, Shtaif B, Levkovitz Y, Nordenberg J, Taler M, Korov I and Weizman A: Phenothiazines induce apoptosis in a B16 mouse melanoma cell line and attenuate in vivo melanoma tumor growth. Oncol Rep 15: 107-112, 2006.

19 Spruce BA, Campbell LA, McTavish N, et al: Small molecule antagonists of the sigma-1 receptor cause selective release of the death program in tumor and self-reliant cells and inhibit tumor growth in vitro and in vivo. Cancer Res 64: 4875-4886, 2004.

20. Bauer S, Duensing A, Demetri GD and Fletcher JA: KIT oncogenic signaling mechanisms in imatinib-resistant gastrointestinal stromal tumor: PI3-kinase/AKT is a crucial survival pathway. Oncogene 26: 7560-7568, 2007.

21. Takayama Y, Kokuryo T, Yokoyama Y, Nagino M, Nimura Y, Senga $T$ and Hamaguchi M: MEK inhibitor enhances the inhibitory effect of imatinib on pancreatic cancer cell growth. Cancer Lett 264: 241-249, 2008.

22. Levkovitz Y, Ben-Shushan G, Hershkovitz A, et al: Antidepressants induce cellular insulin resistance by activation of IRS-1 kinases. Mol Cell Neurosci 36: 305-312, 2007.

23. Ha E, Jung KH, Choe BK, Bae JH, Shin DH, Yim SV and Baik HH: Fluoxetine increases the nitric oxide production via nuclear factor kappa B-mediated pathway in BV2 murine microglial cells. Neurosci Lett 397: 185-189, 2006.
24. Skehan P, Storeng R, Scudiero D, et al: New colorimetric cytotoxicity assay for anticancer-drug screening. J Natl Cancer Inst 82: 1107-1112, 1990.

25. Valeriote $\mathrm{F}$ and Lin H: Synergistic interaction of anti cancer agents: a cellular perspective. Cancer Chemother Rep 59: 895-900, 1975.

26. Koren R, Rocker D, Kotestiano O, Liberman UA and Ravid A: Synergistic anti cancer activity of 1,25-dihydroxyvitamin D3 and immune cytokines: the involvement of reactive oxygen species. J Steroid Biochem Mol Biol 73: 105-112, 2000.

27. Vindel $\varnothing \mathrm{v}$ LL, Christensen IJ and Nissen NI: A detergent-trypsin method for the preparation of nuclei for flow cytometric DNA analysis. Cytometry 3: 323-327, 1983.

28. Levkovitz Y, Gil-Ad I, Zeldich E, Dayag M and Weizman A: Differential induction of apoptosis by antidepressants in glioma and neuroblastoma cell lines: evidence for p-c-Jun, cytochrome c, and caspase-3 involvement. J Mol Neurosci 27: 29-42, 2005.

29. Gasparov VS and Degtiar VG: Protein determination by binding with the dye Coomassie brilliant blue G-250. Biokhimiia 59: 763-777, 1994.

30. Glass-Marmor L, Morgenstern H and Beitner R: Calmodulin antagonists decrease glucose 1,6-bisphosphate, fructose 1,6bisphosphate, ATP and viability of melanoma cells. Eur J Pharmacol 313: 265-271, 1996.

31. Kerkelä R, Grazette L, Yacobi R, et al: Cardiotoxicity of the cancer therapeutic agent imatinib mesylate. Nat Med 12: 908-916, 2006.

32. Yoshia K: Regulation for nuclear targeting of the Abl tyrosine kinase in response to DNA damage. Adv Exp Med Biol 604: $155-165,2007$

33. Ren H, Tan X, Dong Y, Giese A, Chou TC, Rainov N and Yang B: Differential effect of imatinib and synergism of combination treatment with chemotherapeutic agents in malignant glioma cells. Basic Clin Pharmacol Toxicol 104: 241-252, 2009.

34. Polymeropoulos MH, Licamele L, Volpi S, et al: Common effect of antipsychotics on the biosynthesis and regulation of fatty acids and cholesterol supports a key role of lipid homeostasis in schizophrenia. Schizophr Res 108: 134-142, 2009.

35. Mercier G, Lennon AM, Renouf B, Dessouroux A, Ramaugé M, Courtin F and Pierre M: MAP kinase activation by fluoxetine and its relation to gene expression in cultured rat astrocytes. J Mol Neurosci 24: 207-216, 2004.

36. Kubo T, Piperdi S, Rosenblum J, et al: Platelet-derived growth factor receptor as a prognostic marker and a therapeutic target for imatinib mesylate therapy in osteosarcoma. Cancer 112: 2119-2129, 2008

37. Lee EJ, Moon GS, Choi WS, Kim WJ and Moon SK: Naringininduced p21WAF1-mediated G(1)-phase cell cycle arrest via activation of the Ras/Raf/ERK signaling pathway in vascular smooth muscle cells. Food Chem Toxicol 46: 3800-3807, 2008.

38. Thomas J, Wang L, Clark RE, et al: Active transport of imatinib into and out of cells: implications for drug resistance. Blood 104: 3739-3745, 2004

39. Crossman LC, Druker BJ, Deininger MW, et al: hOCT 1 and resistance to imatinib. Blood 106: 1133-1134, 2005.

40. White DL, Saunders VA, Dang P, et al: OCT-1-mediated influx is a key determinant of the intracellular uptake of imatinib but not nilotinib (AMN107): reduced OCT-1 activity is the cause of low in vitro sensitivity to imatinib. Blood 108: 697-704, 2006.

41. Gil-Ad I, Zolokov A, Lomnitski L, et al: Evaluation of the potential anti-cancer activity of the antidepressant sertraline in human colon cancer cell lines and in colorectal cancerxenografted mice. Int J Oncol 33: 277-286, 2008. 